\title{
Electrocatalytic Process for Ammonia Electrolysis: A Remediation Technique with Hydrogen Co-Generation
}

\author{
Phillimon Modisha, Dmitri Bessarabov* \\ HySA Infrastructure Centre of Competence, North-West University, Faculty of Engineering, Private \\ Bag X6001, Potchefstroom Campus, 2520, South Africa \\ *E-mail: dmitri.bessarabov@nwu.ac.za
}

doi: $10.20964 / 2016.08 .54$

Received: 13 May 2016 / Accepted: 10 June 2016 / Published: 7 July 2016

\begin{abstract}
Alkaline ammonia electrocatalysis offers a favorable technique for hydrogen generation and simultaneous conservation of environmental sustainability. In this work, the electrooxidation of ammonia on platinum-Iridium (Pt-Ir) electrocatalyst was studied in $5 \mathrm{M}$ potassium hydroxide (KOH) solution. The effects of operating conditions such as, temperature and ammonia $\left(\mathrm{NH}_{3}\right)$ concentration were investigated. Ammonia electrooxidation current density increased at elevated temperature and ammonia concentration. The maximum ammonia conversion was $78 \%$ for $2300 \mathrm{ppm}$ ammonia. Furthermore, the maximum hydrogen flow rate obtained was $25 \mathrm{~L} / \mathrm{h}$ and the corresponding energy consumption is $1.6 \mathrm{~W} \mathrm{~h} / \mathrm{L}-\mathrm{H}_{2}$. The hydrogen purity obtained from the gas chromatography was $86 \%$. Ammonia is poisonous to the proton exchange membrane (PEM), hence ammonia ion selective electrode was used to determine the amount of ammonia present in $\mathrm{H}_{2}$ gas stream produced and was found to be $<0.1 \mathrm{ppm}$.
\end{abstract}

Keywords: Ammonia electrolysis, Pt-Ir electrocatalyst, hydrogen production, fuel cell, ammonia removal

\section{FULLTEXT}

(C) 2016 The Authors. Published by ESG (www.electrochemsci.org). This article is an open access article distributed under the terms and conditions of the Creative Commons Attribution license (http://creativecommons.org/licenses/by/4.0/). 